\title{
Natalizumab treatment for multiple sclerosis
}

\author{
Tratamento com Natalizumabe para esclerose múltipla
}

Maria Lucia Brito Ferreira

Centro de Referência para Atenção ao Paciente Portador de Doença

Desmielizante, Hospital da

Restauração, Recife PE, Brazil.

\section{Correspondence:}

Maria Lucia Brito Ferreira; Rua

Doutor José Maria, 841; 52040-000

Recife PE, Brasil;

E-mail: lucabrito@uol.com.br

Conflict of interest:

There is no conflict of interest to declare.

Received 23 September 2014

Accepted 01 October 2014
$\mathrm{T}$ he last five years had as benchmark the development of new drugs for treatment of multiple sclerosis. Its treatment has become complex because other aspects must be considered on choosing therapeutic management, as previous use of immunosuppressors, time of disease and more recently virus load.

This issue brings an interesting research on the controversial risk of progressive multifocal leukoencephalopathy (PML) in multiple sclerosis patients treated with Natalizumab. Nali et al. ${ }^{1}$ present a brief review on the PML of patients submitted to Natalizumab treatment for relapsing-remitting multiple sclerosis and describe the results of virus load and JVC/DNA positivity in urine and blood, of a patient, after a 12 months' follow-up.

The central question of this research ${ }^{1}$ seems to be the identification of patients with lower or higher risk for developing PML, which must be considered on prescribing Natalizumab. PML is a devastating condition leading to death or severe disability, that can be the result of reactivation of a previous latent JCV viral infection of urinary tract ${ }^{2}$.

To date, there is no available method to determine which patient will have a highest risk for developing PML and, also, which association can be established between JCV/DNA positivity, JCV viremia and JCV viruria, and $\mathrm{PML}^{3}$.

Actual statistics demonstrate that, among 118,000 patients using Natalizumab, 401 $(0.34 \%)$ developed $\mathrm{PML}^{4}$. Although this is a low percentage, one must evaluate this risk to decide, with the patient, to continue or to change prescription, but it remains controversial. Despite the presence of rearranged forms of JCV virus in urine, there was no viremia or concomitant increased viral load after a 12 months treatment with Natalizumab ${ }^{1}$. These findings of Nali et al. ${ }^{1}$ seem to reinforce the new management algorithm proposed by Sørensen ${ }^{3}$, where JCV positivity may point out to another therapy. This conduct is discussed by Nali et al. ${ }^{1}$, on considering the risks of drug holiday after 12 months of Natalizumab treatment.

A final consideration is that we still know very little on the causation of PML, and other researches will be necessary to investigate also the influence of host immunity ${ }^{5}$, that seems to be relevant as we observe the discrepancy between the widespread prevalence of JCV and the rare occurrence of $\mathrm{PML}^{6}$. This discrepancy suggests the influence of factors other than an altered immune system, as interactions between host and viral factors or viral alterations ${ }^{2}$. This will help us on deciding the best therapy for MS patients, with less PML risk. 
1. Nali LHS, Moraes L, Fink MCD, Callegaro D, Romano CM, Oliveira ACP. Natalizumab treatment for multiple sclerosis: updates and considerations for safer treatment in JCV positive patients. Arq Neuropsiq. 2014;72(12):960-965.

2. Bozic C, Subramanyam M, Richman S, Plavina T, Zhang A, Ticho B. Anti-JC virus (JCV) antibody prevalence in the JCV Epidemiology in MS (JEMS) trial. Eur J Neurol. 2014;21(2):299-304. http://dx.doi.org/ 10.1111/ene.12304

3. Sørensen PS. New management algorithms in multiple sclerosis. Curr. Opin Neurol. 2014;27(3):246-59. http://dx.doi.org/10.1097/WCO. 0000000000000096
4

Biogen Idec Medical Affairs. Tysabri (natalizumab) benefit/risk update \& PML risk stratification. 2013 [cited 2014 Nov] Available from: http://multiple-sclerosis-research.blogspot.com.br/2013/10/ natalizumab-pml-update-september-2013.html

5. Gorelik L, Lerner M, Bixler S, Grossman M, Schlain B, Simon K, et al. Anti-JC virus antibodies: implications for PML risk stratification. Ann Neurol. 2010;68(3):295-303. http://dx.doi.org/10.1002/ana.22128

6. Sørensen PS, Bertolotto A, Edan G, Giovannoni G, Gold R, Havrdova E, et al. Risk stratification for progressive multifocal leukoencephalopathy in patients treated with natalizumab. Mult Scler. 2012;18(2):143-52. http://dx.doi.org/10.1177/1352458511435105 